Check for updates

Cite this: RSC Adv., 2017, 7, 50920

\title{
A study on the synthesis and anion recognition of a chitosan-urea receptor
}

\author{
Kuerbanjiang Rouzi, DD ab Abuderixiti Abulikemu, ${ }^{\mathrm{c}}$ Jie Zhao a and Biao Wu${ }^{* a}$ \\ A new chitosan based colorimetric anion receptor bearing nitrophenyl as a chromogenic signal group, \\ and urea moiety as recognition site was designed and synthesized. The receptor structure was \\ characterized by FTIR and ${ }^{1} \mathrm{H}$ NMR. The sensing abilities of the receptor for anions were investigated \\ with UV-vis methods. During the addition of $\mathrm{PO}_{4}{ }^{3-}$ and $\mathrm{F}^{-}$anions, the sensor responded with \\ a dramatic color change, and no change was observed in the presence of other anions. The UV-vis \\ absorption titration data showed that the receptor shows selective recognition and sensing in DMSO- \\ $\mathrm{H}_{2} \mathrm{O}(1 \%)$ for $\mathrm{PO}_{4}{ }^{3-}$ and $\mathrm{F}^{-}$anions. The Job's curve showed that $3: 2$ stoichiometry complexes were \\ formed between the receptor and the anion.
}

Received 25th August 2017

Accepted 8th October 2017

DOI: $10.1039 / \mathrm{c} 7 \mathrm{ra09431k}$

rsc.li/rsc-advances
It is well-known that urea/thiourea with a nitrophenyl group as a signaling unit showed an enhancement in both the hydrogen-bond donor tendency and acidity. ${ }^{15}$ For example, Aldrey ${ }^{16}$ and others ${ }^{17,18}$ have reported the colorimetric receptors where nitrophenyl was treated as a signaling unit and urea/ thiourea moieties as binding sites.

The selectivity for special analyte of the host molecule could be rationalized on the basis of not only the guest basicity but also shape complementarity between the host and the anionic guests. We recently developed a series of ortho-phenylene bridged oligourea receptors that exhibit excellent binding affinity and selectivity toward tetrahedral anions (sulfate and phosphate) and have proven to be promising receptors for anion coordination and recognition. ${ }^{19}$

Chitosan (CS) is a linear $\beta$-(1,4)-linked polysaccharide that is composed of glucosamine and $\mathrm{N}$-acetylglucosamine obtained by the partial deacetylation of chitin-the second most abundant biopolymer in nature. ${ }^{20-22}$ Chitosan is non-toxic, biocompatible and biodegradable. It is widely used in biotechnology, pharmaceuticals, cosmetics, agriculture, food science and textiles. ${ }^{23}$ However, due to strong intra- and intermolecular hydrogen bonding interactions, chitosan is only soluble in acids. It is insoluble in neutral or alkaline aqueous solutions and thus its utility is largely limited. Therefore, it is necessary to introduce functional groups to transform the chemical structure of chitosan as well as to improve its solubility, functionality, and applications.

In recent years, chitosan thiourea and its derivatives have been extensively studied in various applications such as antimicrobial and antifungal activity, ${ }^{24-28}$ chelating adsorbents for adsorption of heavy metal ions, ${ }^{29}$ inorganic anions (such as fluoride, sulfate, nitrate, and phosphate), ${ }^{30-32}$ and macromolecular organic compounds. ${ }^{33}$ In addition, chitosan and its derivatives have been used as stationary materials for
${ }^{a}$ Key Laboratory of Synthetic and Natural Functional Molecule Chemistry of the Ministry of Education, College of Chemistry and Materials Science, Northwest University, Xi'an, Shaanxi, 710069, P. R. China. E-mail: wubiao@nwu.edu.cn; krbnjn2003@126.com; Fax: +862981535020; Tel: +862981535020

${ }^{b}$ Institute of Chemistry and Chemical Engineering, Xinjiang University, Urumqi, 830046, P. R. China

${ }^{c}$ College of Chemistry and Chemical Engineering, Xinjiang Normal University, Urumqi, 830054, Xinjiang, P. R. China.E-mail: aarexit@mail.ustc.edu.cn 
chromatographic columns ${ }^{34}$ as a colorimetric optical sensor for the detection of $\mathrm{Ni}^{2+}, \mathrm{Pd}^{2+}, \mathrm{Cd}^{2+}$, and $\mathrm{Hg}^{2+}$ ions, ${ }^{35-38}$ as a carrier in biosensors, ${ }^{39}$ as an electrochemical sensor for the detection of $\mathrm{F}^{-}, \mathrm{NO}_{3}{ }^{-}, \mathrm{I}^{-}$anions, ${ }^{40,41}$ or as a photochemical sensor for the detection of $\mathrm{H}_{2} \mathrm{~S}, \mathrm{NH}_{3}$, or $\mathrm{CO}$ gases. ${ }^{42-44}$

However, to the best of our knowledge, there is no report showing about chitosan (thio) urea as an anion recognition tool. Here we designed and synthesized chitosan based colorimetric anion receptors for three main reasons: (i) chitosan contains many free and active groups of amino $\left(-\mathrm{NH}_{2}\right)$ and hydroxyl $(-\mathrm{OH})$. Multiple urea, hydroxyl and amino groups are good hydrogen bond donors for the construction of the chitosan based anion receptors. It is known that stronger interactions in the host-guest systems are usually a consequence of a larger number of H-bonds in the complex. ${ }^{10}$ Therefore, the complex stability highly depends on the strength and the number of the $\mathrm{H}$-bonds. (ii) The 4-nitrophenyl group was appended to the urea moiety, and the presence of $-\mathrm{NO}_{2}$ - electron-withdrawing group enhanced the acidity, and colorimetric recognition ability of the receptor and (iii) the receptor synthesis is simple.

Here, a 4-nitrophenylurea chitosan (CS-NPU) receptor was prepared through the reaction of chitosan with 4-nitrophenyl isocyanate. The receptor structure was characterized by FTIR and ${ }^{1} \mathrm{H}$ NMR and its anion sensing properties were studied by UV-vis analytical methods. In addition, sensing behaviors can be realized via the "naked eye" determination because it has a remarkable color response.

\section{Experimental}

\section{Materials and chemicals}

Chitosan (degree of deacetylation $=95.20 \%$, average molecular weight $M_{\eta}=4.75 \times 10^{5}$, viscosity $=100-200 \mathrm{mPa}$ s) was purchased from Shanghai Aladdin Industrial Corporation (China). This was dried in a vacuum drying at $50{ }^{\circ} \mathrm{C}$ for $48 \mathrm{~h}$ before use. The 4-nitrophenyl isocyanate (NPI) and tetrabutylammonium salts (TBA) of all anions (where $\left[(\mathrm{Bu})_{4} \mathrm{~N}\right]_{2} \mathrm{SO}_{4}$ is $50 \%$ water solution) were purchased from Alfa Aesar and used directly. The DMSO was dried prior to use with $\mathrm{CaH}_{2}$. It was distilled under reduced pressure. Other reagents were of analytical grade without further purification.

\section{Determination of degree of deacetylation (DDA) and molecular weight}

The degree of deacetylation of chitosan was determined via a potentiometric titration according to the literature..$^{45} 0.2 \mathrm{~g}$ of chitosan was dissolved in $25 \mathrm{~mL}$ of $0.1 \mathrm{M} \mathrm{HCl}$ and excess $\mathrm{HCl}$ was back titrated with a solution of $0.1 \mathrm{M} \mathrm{NaOH}$ using a pHSJ-4F meter (INESA, Shanghai). The differential and integral titration curves were drawn between solution $\mathrm{pH}$ and volume of alkali added. This produced an integral curve with two inflexions. The DDA of chitosan has been calculated as follows:

$$
\mathrm{DDA}=\left(\frac{203 Q}{1+42 Q}\right) \times 100 \% \quad Q=\frac{N \Delta V}{m}
$$

here $\Delta V$ is the differential volume of $\mathrm{NaOH}$ between two inflexion points, $m$ is dry weight of CS sample and $N$ is the concentration of $\mathrm{NaOH}$ used in the titration.

The molecular weight was determined by measuring relative viscosity with an Ubbelohde viscometer at $25 \pm 0.5{ }^{\circ} \mathrm{C}$. The solvent system was $0.1 \mathrm{M} \mathrm{CH}_{3} \mathrm{COOH}$ and $0.1 \mathrm{M} \mathrm{CH}_{3} \mathrm{COONa}$. The molecular weight was calculated from the intrinsic viscosity based on the Mark-Houwink eqn (2):

$$
[\eta]=K M^{\alpha}
$$

here $\alpha$ and $K$ are Mark Houwink constants; we used $\alpha=0.93$ and $K=1.81 \times 10^{-3} \mathrm{~cm}^{3} \mathrm{~g}^{-1}$ from the literature. ${ }^{46,47}$

\section{Degradation of CS by hydrogen peroxide}

The degradation process of chitosan was performed according to the literature. ${ }^{48}$ Chitosan $(6 \mathrm{~g})$ was dissolved in $200 \mathrm{~mL}$ acetic acid solution $5.0 \%(\mathrm{w} / \mathrm{v})$ under room temperature for $1 \mathrm{~h}$ with stirring and heating to $65^{\circ} \mathrm{C}$. Next, $6 \mathrm{~mL} \mathrm{H}_{2} \mathrm{O}_{2}$ was added to obtain the CS solution. The resulting solution was stirred at $65{ }^{\circ} \mathrm{C}$ for $6 \mathrm{~h}$. The solution was added into a $10 \%$ sodium hydroxide solution. The product precipitated and was then filtered and washed with deionized water until the $\mathrm{pH}=7$. The solid was lyophilized for three days at $-50{ }^{\circ} \mathrm{C}$. The deacetylation degree of the degradation CS was $94.30 \%$, and the $M_{\eta}$ value was $2.37 \times 10^{4} \mathrm{~g} \mathrm{~mol}^{-1}$.

\section{Preparation of chitosan-nitrophenylurea (CS-NPU) receptor}

The chitosan was modified via reaction between the amino group on the chitosan and the active isocyanate group of NPI as presented in Scheme 1. The treated CS (calculated by the glucosamine units: $0.180 \mathrm{~g}, 1 \mathrm{mmol}$ ) was added into a twonecked flask evacuated under vacuum and flushed with dry nitrogen three times. This was then added into $30 \mathrm{~mL}$ of dry DMSO in the flask. The mixture was stirred $30 \mathrm{~h}$ at $60^{\circ} \mathrm{C}$. Then NPI $(0.246 \mathrm{~g}, 1.5 \mathrm{mmol})$ was added into the flask, and the resulting mixture was stirred at room temperature for $48 \mathrm{~h}$. Finally, a pale yellow solid was filtered, washed three times with DMSO and acetone and then dried in vacuum.
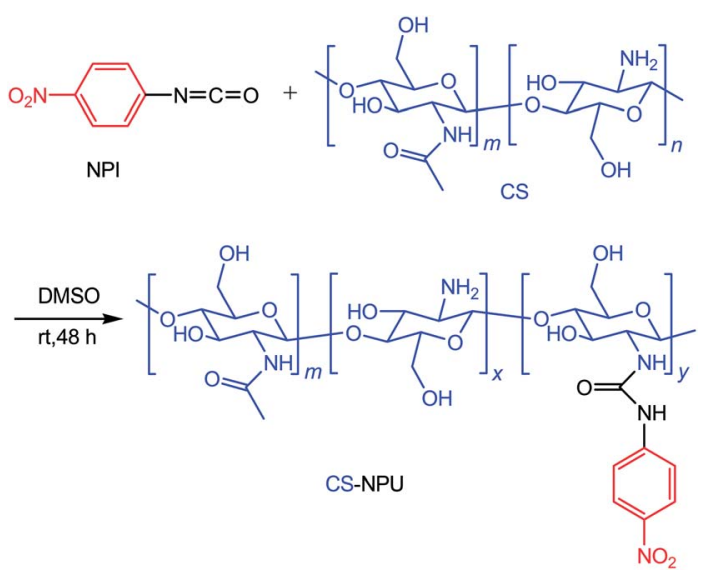

Scheme 1 Synthetic route of CS-NPU. 


\section{Characterizations}

\section{Fourier transform infrared spectroscopy}

Fourier transform infrared spectra (FTIR) of CS-NPU were recorded in solid state using BRUKER EQUINOX-55 spectrometer (Germany). The spectra were collected in $4000-400 \mathrm{~cm}^{-1}$ region using $\mathrm{KBr}$ pellets. All samples were dried in a vacuum oven at $60{ }^{\circ} \mathrm{C}$ for $24 \mathrm{~h}$ before testing.

\section{Nuclear magnetic resonance spectroscopy}

${ }^{1} \mathrm{H}$ NMR spectroscopy was used to determine the chemical structures of the CS and CS-NPU. The ${ }^{1} \mathrm{H}$ NMR spectra were obtained using a VARIAN INOVA-400 spectrometer $(400 \mathrm{MHz}$, USA) with $5 \%$ acetic acid- $\mathrm{d}_{4} /$ water- $\mathrm{d}_{2}$ as solvents.

\section{UV-vis titrations}

The absorption spectra were recorded with a UV-178 UV-visible spectrophotometer (Shimadzu, Japan). The concentration of the receptor solution $\left(1.0 \times 10^{-5} \mathrm{M}\right)$ in $\mathrm{DMSO} / \mathrm{H}_{2} \mathrm{O}$ was calculated on the basis of the monomeric units and the guest anions $(2.0 \times$ $\left.10^{-3} \mathrm{M}\right)$ in DMSO. In each experiment a small amount $(2-5 \mu \mathrm{L})$ of guest anion samples were added to the receptor $\mathrm{L}(2 \mathrm{~mL})$ solution. The spectrum was then scanned. All measurements were performed at room temperature.

\section{Absorption titrations and Hill plots ${ }^{49}$}

The sample solutions with varying amounts of anions were prepared similar to the above procedure. The UV-vis absorption was measured. The titration curve was obtained by plotting the absorbance at the proper wavelength versus the [anion]/[monomeric units of receptor] ratio. The binding data were further analyzed using the Hill equation (eqn (3)):

$$
\log [Y /(1-Y)]=n \log [\text { anion }]+n \log K_{\mathrm{a}}
$$

here $Y, K_{\mathrm{a}}$, and $n$ represent the fractional saturation of the host, the apparent binding constant and the Hill coefficient, respectively. The $Y$ value was calculated via eqn (4):

$$
Y=\frac{\Delta A_{\mathrm{obs}}}{\Delta A_{\max }}=\frac{\left(A_{\mathrm{obs}}-A_{0}\right)}{\left(A_{\max }-A_{0}\right)}
$$

here $A_{0}, A_{\mathrm{obs}}$, and $A_{\max }$ represent the inherent absorbance of urea chitosan sample, the absorbance in the presence of anion guests and the maximum absorbance obtained when the absorption change was completed at the selected wavelength. The $K_{\mathrm{a}}$ and $n$ values were determined from the slope and $Y$ intercept in the resulting Hill plots.

\section{Solubility test}

The solubility of the chitosan and the modified chitosan was tested in common organic solvents such as acetone, carbon tetrachloride, dichloromethane, trichloromethane, ethanol, methanol, tetrahydrofuran(THF), $N, N$-dimethylformamide (DMF), dimethyl sulfoxide (DMSO) at $25{ }^{\circ} \mathrm{C}$. The samples were soaked in each solvent at the concentration of $5 \mathrm{mg} \mathrm{mL} L^{-1}$, the results are presented in Table 2 .

\section{Results and discussion}

\section{Characterization of CS-NPU receptor}

FT-IR analysis. The FTIR spectra of the CS, degradation of CS and CS-NPU are shown in Fig. 1. Fig. 1(a) shows a broad and strong absorption band at $3409 \mathrm{~cm}^{-1}$. This was attributed to the overlapping of the stretching vibrations of both amine $(-\mathrm{NH})$ and hydroxyl $(-\mathrm{OH})$ groups. The band at $2908 \mathrm{~cm}^{-1}$ belongs to $-\mathrm{CH}_{3}$ (the residual acetamide group), and the band around $2861 \mathrm{~cm}^{-1}$ is the vibration of the $\mathrm{C}-\mathrm{H}$ group. There were characteristic bands such as the amide I band at $1637 \mathrm{~cm}^{-1}(\nu(\mathrm{C}=\mathrm{O}))$, the amide II $\delta(\mathrm{N}-\mathrm{H})$ at $1602 \mathrm{~cm}^{-1},{ }^{50}$ and the $\nu(\mathrm{C}-\mathrm{N})$ at $1592 \mathrm{~cm}^{-1}$. The $\delta\left(\mathrm{CH}_{2}\right)$ was at $1425 \mathrm{~cm}^{-1}$ and the $\delta\left(\mathrm{CH}_{3}\right)$ was at $1378 \mathrm{~cm}^{-1}$. There were pronounced bands at $1170 \mathrm{~cm}^{-1}$ and $1072 \mathrm{~cm}^{-1}$ for the C-O-C and C-O stretching vibrations, respectively. Degraded CS shows few new or enhanced absorption peaks. The intensity of the absorption peak is the main difference in the degraded material. This indicates that CS and its degradation products have the same molecular structure. The basic structural unit CS survives oxidative degradation. This further shows that the active functional groups $-\mathrm{NH}_{2}$ and $-\mathrm{OH}$ remain (Fig. 1(b)). According to the characteristic frequency of the infrared absorption spectrum, there are new peaks, at $1698 \mathrm{~cm}^{-1}$ urea $\nu(\mathrm{C}=\mathrm{O})$, $1327 \mathrm{~cm}^{-1}\left(-\mathrm{NO}_{2}\right), 1517 \mathrm{~cm}^{-1}$ (phenyl) and $709 \mathrm{~cm}^{-1}$ (phenyl) (Fig. 1(c)). The characteristic vibration peak of the $\mathrm{C}=\mathrm{O}$ stretching of the urea moiety of modified chitosan is consistent with the reported literature. ${ }^{51}$

The analysis of ${ }^{\mathbf{1}} \mathbf{H}$ NMR. Fig. 2 compares the ${ }^{1} \mathrm{H}$ NMR spectra of CS and CS-NPU with the assignments of all the protons. The chitosan spectrum (Fig. 2(a)) showed a small signal at $\delta 2.14 \mathrm{ppm}$ assigned to the methyl protons in $N$-acetylated glucosamine unit. ${ }^{52}$ The signal at $\delta 3.28 \mathrm{ppm}$ was assigned to the C2 proton of glucosamine and the $N$-acetylated glucosamine unit. There are peaks from $\delta 3.8$ to $4.0 \mathrm{ppm}$ that were attributed to C3-C6 protons of glucosamine and the $\mathrm{N}$-acetylated

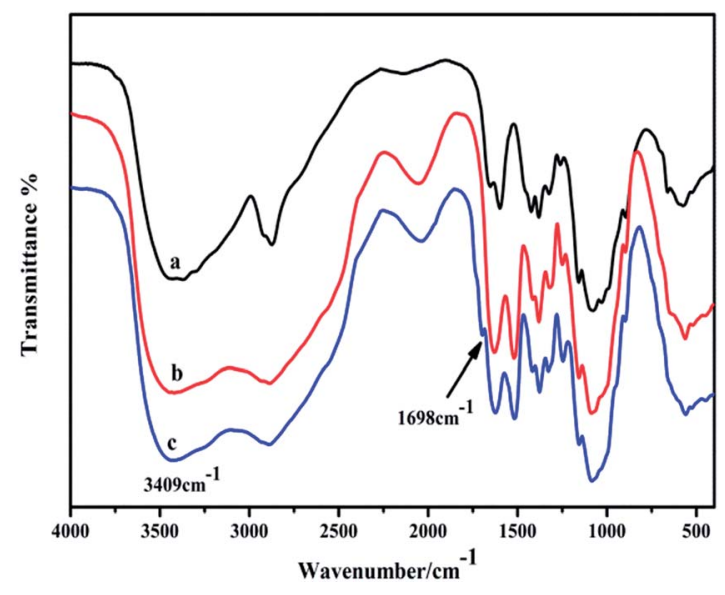

Fig. 1 FTIR spectra of (a) CS, (b) degraded-CS and (c) CS-NPU. 


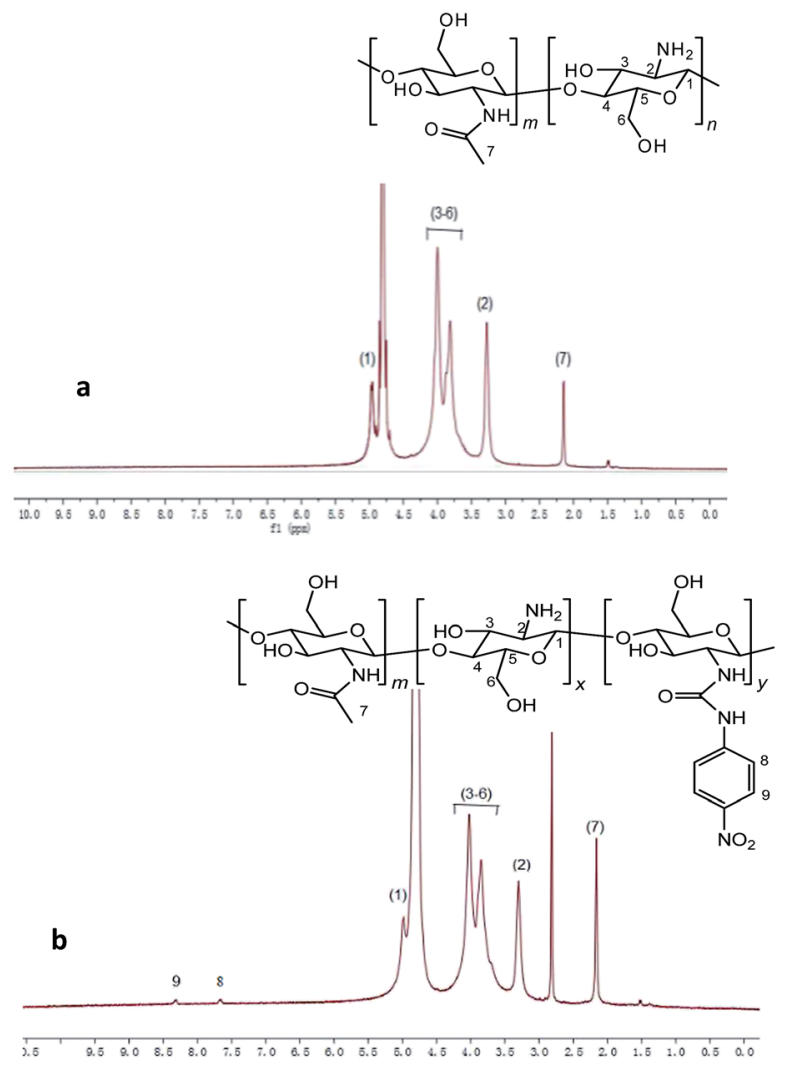

Fig. $2{ }^{1} \mathrm{H}$ NMR spectrum of (a) CS and (b) CS-NPU with acetic acid- $d_{4} /$ water- $\mathrm{d}_{2}$ as solvent.

glucosamine unit. There was a signal at about $\delta 4.85 \mathrm{ppm}$ from the $\mathrm{C} 1$ proton of glucosamine and $N$-acetylated glucosamine unit. ${ }^{53,54}$ Similar results were also reported in the literature. ${ }^{55}$

The ${ }^{1} \mathrm{H}$ NMR spectrum of CS-NPU is shown in (Fig. 2(b)). The aromatic proton peaks from $\delta 7.50$ to $8.50 \mathrm{ppm}$ are characteristic for mono substituted benzene derivatives. Based on the assignment of the ${ }^{1} \mathrm{H}$ NMR spectra of CS-NPU, we concluded that the phenyl urea group has been successfully introduced to the chitosan. ${ }^{29,48}$

\section{Recognition performance}

Naked eye detection. The colorimetric detection experiment was performed in DMSO by addition of the various anions to a solution of receptors $\left(4.0 \times 10^{-5} \mathrm{M}\right)$. The solution changed from colorless to yellow for $\mathrm{PO}_{4}{ }^{3-}$ and yellowish for $\mathrm{F}^{-}$anion (10 equiv.) (Fig. 3). This was easily observed by the naked eye. However, no color change was seen with $\mathrm{Cl}^{-}, \mathrm{Br}^{-}, \mathrm{I}^{-}, \mathrm{NO}_{3}{ }^{-}$, $\mathrm{PF}_{6}{ }^{-}, \mathrm{ClO}_{4}{ }^{-}, \mathrm{AcO}^{-}, \mathrm{H}_{2} \mathrm{PO}_{4}{ }^{-}, \mathrm{HSO}_{4}{ }^{-}$, and $\mathrm{SO}_{4}{ }^{2-}$. The color changes are most probably due to high negative charge density

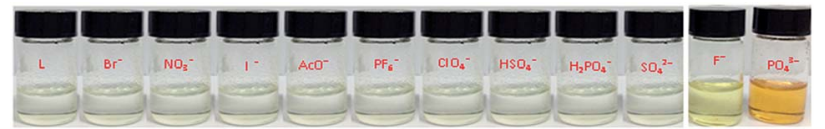

Fig. 3 Naked-eye images of $\mathrm{L}$ in $\mathrm{DMSO} / \mathrm{H}_{2} \mathrm{O}$ solutions upon the addition of 10.0 equiv. of TBA salt of various anions. on $\mathrm{F}^{-}$and $\mathrm{PO}_{4}{ }^{3-}$. These result in the strong hydrogen bonding with $\mathrm{NH}$ and $\mathrm{OH}$ in the receptor. The formation of these hydrogen bonds affects the electronic properties of the chromophore as well as the strong hydrogen bond interactions between electron deficient urea moieties and the $\mathrm{F}^{-}$or $\mathrm{PO}_{4}{ }^{3-}$ bound hydroxyl group. ${ }^{56}$

\section{UV-vis spectra titrations}

The anion sensing behavior of receptor $\left(4.0 \times 10^{-5} \mathrm{M}\right)$ was determined by UV-vis spectrophotometric methods in DMSO/ $\mathrm{H}_{2} \mathrm{O}$ solution. Absorption titrations were carried out with a receptor $\left(4.0 \times 10^{-5} \mathrm{M}\right)$ in $\mathrm{DMSO} / \mathrm{H}_{2} \mathrm{O}$. The receptor was titrated upon incremental addition of tetrabutylammonium fluoride $\left(1.0 \times 10^{-5} \mathrm{M}\right)$ and phosphate $\left(1.0 \times 10^{-5} \mathrm{M}\right)$ in DMSO up to 2 equivalents. The titrations were carried out for all anions, and the resulting spectra are shown in Fig. 4. The UV-vis spectra of the receptor in $\mathrm{DMSO} / \mathrm{H}_{2} \mathrm{O}$ were dominated by strong absorption peak at $351 \mathrm{~nm}$.

During the addition of $\mathrm{PO}_{4}{ }^{3-}$ to the solution of receptor, prominent changes were observed in UV-vis absorption spectra due to complexation between receptor and anion. The ICT band at $351 \mathrm{~nm}$ for the receptor is shown in Fig. 5(a). This disappears gradually upon formation of new peak at $468 \mathrm{~nm}$ (bathochromic shift). Clear isosbestic points were observed at 317 and 412 for $\mathrm{L}$. The absorbance intensity of $\mathrm{L}$ was saturated with 1200 equiv. of $\mathrm{PO}_{4}{ }^{3-}$. On the other hand, Fig. 6(a) shows that as the $\mathrm{F}^{-}$anion increased, the absorption peak at $351 \mathrm{~nm}$ gradually decrease, and a new peak appeared at $486 \mathrm{~nm}$. Clear isosbestic points were observed at 286 and $409 \mathrm{~nm}$. The absorbance intensity of $\mathrm{L}$ was saturated with 875 equiv. of $\mathrm{F}^{-}$. The addition of other anionic species as their tetrabutylammonium salts did not give any response. This shows the specificity of the receptor for selective binding interaction with $\mathrm{PO}_{4}{ }^{3-}$ and $\mathrm{F}^{-}$anions. The data confirm that the receptor has higher selectivity for phosphate and fluoride over other anions.

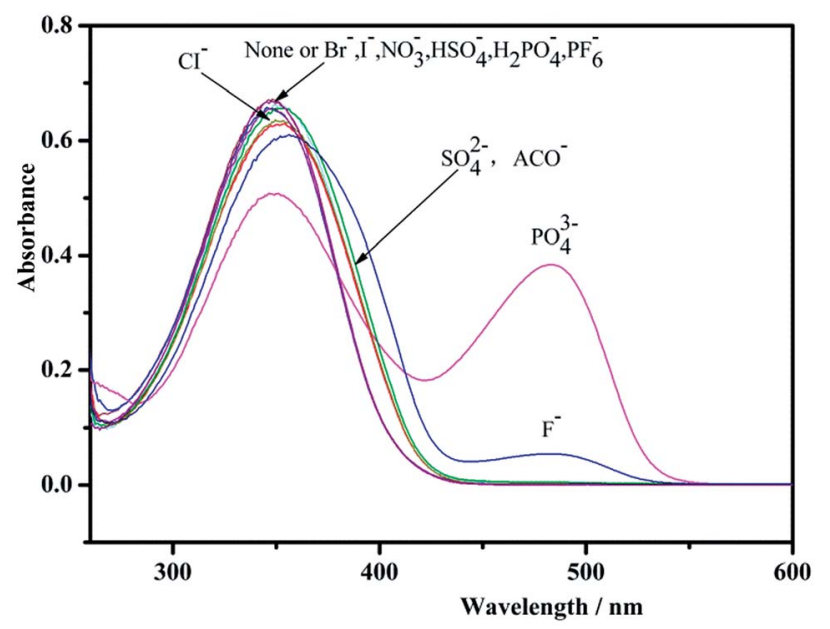

Fig. 4 UV-vis absorbance of $\mathrm{L}$ in $\mathrm{DMSO} / \mathrm{H}_{2} \mathrm{O}$ upon addition of different anions ([anion]/[L] $=10$ ); [monomeric units of $L$ ] $=1 \times$ $10^{-5} \mathrm{~mol} \mathrm{~L}^{-1}$. 

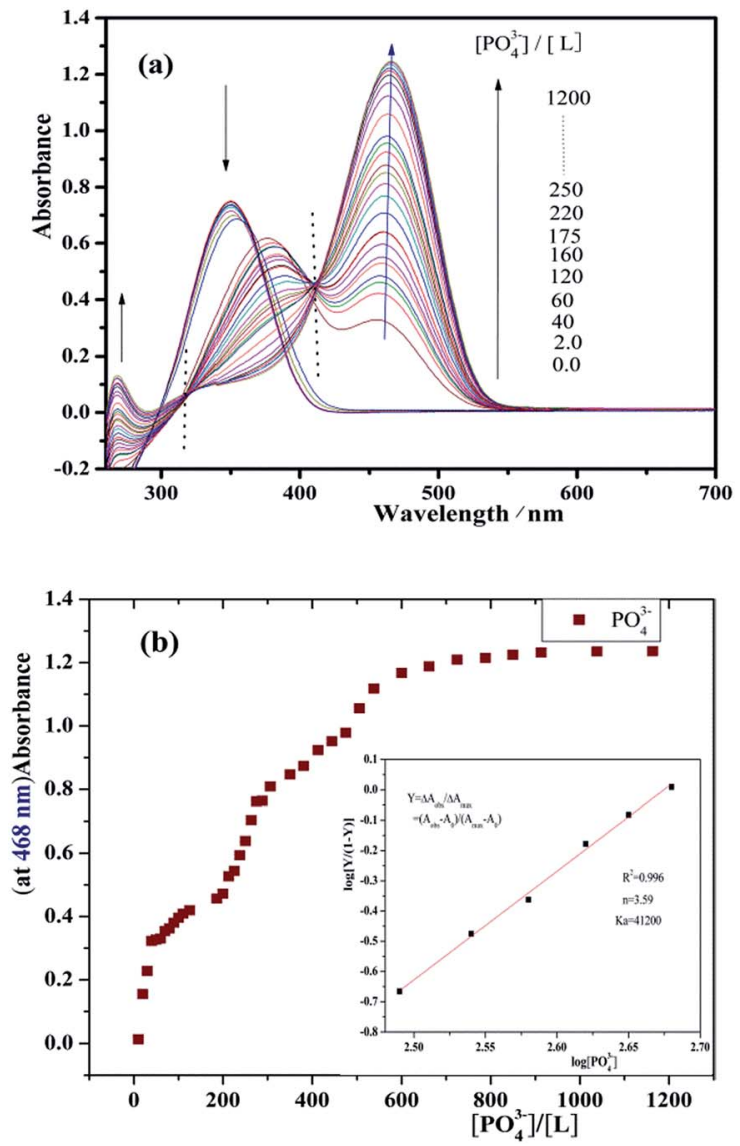

Fig. 5 (a) UV-vis spectral titration of receptor $\mathrm{L}$ with $\mathrm{PO}_{4}{ }^{3-}$ in DMSO $(99 \%) / \mathrm{H}_{2} \mathrm{O}(1 \%)$ solution; (b) the absorbance titration curve of $\mathrm{L}$ at $468 \mathrm{~nm}$ upon addition of $\mathrm{PO}_{4}{ }^{3-}$; inset: Hill plot analysis the receptor and $\mathrm{PO}_{4}{ }^{3-}$.

\section{The Job's plot}

Next, we used a Job's plot (continuous variation) to establish the stoichiometric ratio between receptor and anionic guests by continuous variation in mole fraction of $\mathrm{L}$ ([host]/[host] + [guest]), and the total concentration of $\mathrm{L}$ and anionic guest was constant $\left(1.0 \times 10^{-4} \mathrm{M}\right)$. Fig. 7 shows the Job plot for $\mathrm{L}$ and the anion complex. The receptor $\mathrm{L} / \mathrm{F}^{-}$complex concentration approaches a maximum when the mole fraction of $\mathrm{L}$ is 0.6 . This means that $\mathrm{L}$ and $\mathrm{F}^{-}$form $3: 2$ complexes. We found similar stoichiometric ratios for $\mathrm{L}$ with $\mathrm{PO}_{4}{ }^{3-}$.

\section{Hill plot analysis}

On the basis of $3: 2$ stoichiometry, the corresponding binding constants $\left(K_{\mathrm{a}}\right)$ of $\mathrm{L}$ for $\mathrm{F}^{-}$and $\mathrm{PO}_{4}{ }^{3-}$ anions were calculated in DMSO based on the UV-vis titration experiments by Hill plots the results are presented in Table 1 . Hill plots of $\mathrm{L}$ for $\mathrm{F}^{-}$and $\mathrm{PO}_{4}{ }^{3-}$ are shown in Fig. 5(b) and 6(b). The slope and the intercept of Hill plots shows that $K_{\mathrm{a}}=4.12 \times 10^{4} \mathrm{M}^{-1}$ and $n=$ 3.59 for $\mathrm{L} / \mathrm{PO}_{4}{ }^{3-}$ (correlation coefficient: $R^{2}=0.996$ ) and $K_{\mathrm{a}}=$ $2.86 \times 10^{4} \mathrm{M}^{-1}$ and $n=2.12$ for $\mathrm{L} / \mathrm{F}^{-}\left(R^{2}=0.990\right)$. This shows that $\mathrm{L}$ has strong binding ability to $\mathrm{PO}_{4}{ }^{3-}$ and $\mathrm{F}^{-}$, and it forms a stable complex. The $n$ value was greater than 1 , and the titration curve of $\mathrm{L}$ was $\mathrm{S}$ shaped. This indicated that the effects are positive and cooperative between $\mathrm{L}$ and $\mathrm{PO}_{4}{ }^{3-}$ or $\mathrm{F}^{-} .^{.57}$
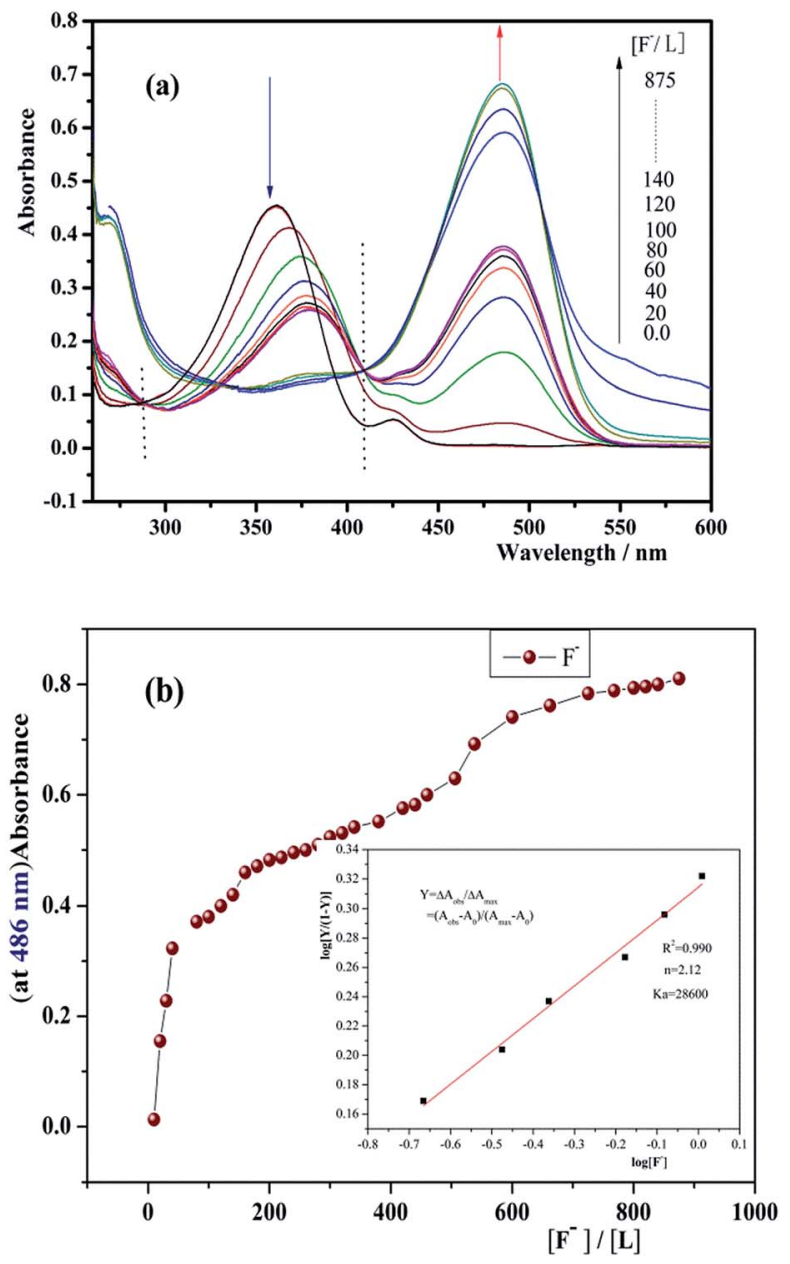

Fig. 6 (a) UV-vis spectral titration of receptor $L$ with $\mathrm{F}^{-}$in DMSO (99\%)/ $\mathrm{H}_{2} \mathrm{O}(1 \%)$ solution; (b) the absorbance titration curve of $\mathrm{L}$ at $486 \mathrm{~nm}$ upon addition of $\mathrm{F}^{-}$. Inset: Hill plot analysis the receptor and $\mathrm{F}^{-}$.

\section{Solubility of NPU-chitosan}

The solubility of the CS and CS-NPU were studied in different solvents at $25{ }^{\circ} \mathrm{C}$ (Table 2). CS is insoluble in water or any selected organic solvent but soluble in dilute aqueous acids due

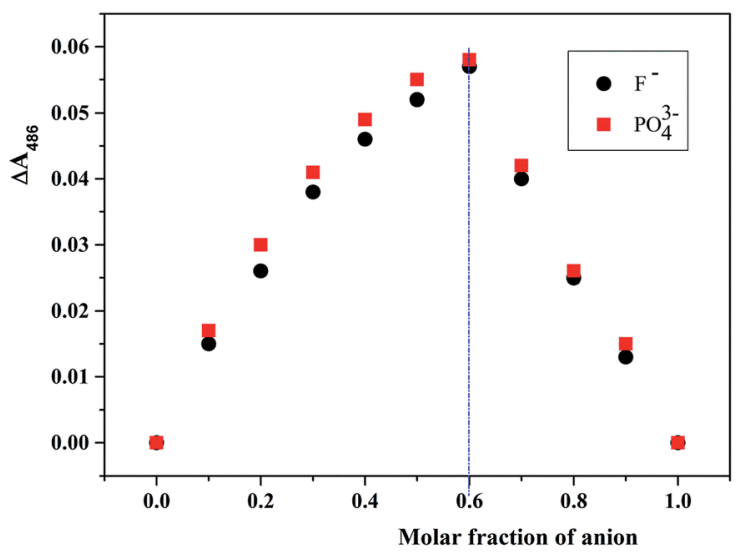

Fig. 7 Job plot for $L$ and anion complex. 
Table 1 Apparent binding constants of $\mathrm{L}_{\text {with }} \mathrm{F}^{-}$and $\mathrm{PO}_{4}{ }^{3-}$ anions in DMSO

\begin{tabular}{lll}
\hline Receptor & anion & $K_{\mathrm{a}}\left(\mathrm{M}^{-1}\right)$ \\
\hline $\mathrm{L}$ & $\mathrm{F}^{-}$ & $4.12 \times 10^{4}$ \\
$\mathrm{~L}$ & $\mathrm{PO}_{4}{ }^{3-}$ & $2.86 \times 10^{4}$
\end{tabular}

to protonation of the amino groups. As shown in the table, CSNPU is insoluble in carbon tetrachloride, dichloromethane, acetone, trichloromethane, ethanol, methanol, and THF, and it is swelled in strong polar solvents such as DMSO and DMF. NPU-CS is soluble in $\mathrm{DMSO} / \mathrm{H}_{2} \mathrm{O}$ solution and acetic acid solution $(5 \%, \mathrm{v} / \mathrm{v})$.

\section{Possible recognition mechanism}

The solution is yellow when the receptor molecules coexist with phosphate anion. Upon addition of a small amount of proton solvent methanol, the solution gradually became colorless. The absorption peak at $351 \mathrm{~nm}$ increased gradually to the state without addition of anions. At the same time, the absorption peak of $468 \mathrm{~nm}$ gradually disappeared. This may be due to the competition of hydrogen bonding site of the methanol molecule to the anion with receptor molecule. These spectral data indicate the essence of the hydrogen bonding between the host and guest.

Fabbrizzi and other research group's studies showed that (thio)urea is a good H-bonds donor and excellent receptor for tetrahedral anions and Y-shaped anions through the formation of multi topic $\mathrm{H}$-bonds. ${ }^{\mathbf{1 4 5 8}}$ Thus, for a given $\mathrm{NH}$-containing receptor (the acid), selectivity should be mainly related to the

Table 2 Solubility of chitosan and phenylurea-chitosan in organic solvent ${ }^{a}$

\begin{tabular}{llll}
\hline & Solubility & & \\
\cline { 2 - 4 } Sample & DMSO & DMF & Ethanol \\
\hline CS & - & - & - \\
NPU-CS & \pm & \pm & - \\
\hline
\end{tabular}

\begin{tabular}{llll}
\hline & Solubility & & \\
\cline { 2 - 4 } & Trichloromethane & $\begin{array}{l}\text { Carbon } \\
\text { tetrachloride }\end{array}$ & Methanol \\
\hline CS & - & - & - \\
NPU-CS & - & - & - \\
\hline
\end{tabular}

\begin{tabular}{llll}
\hline & Solubility & & \\
\cline { 2 - 3 } Sample & THF & Acetone & Dichloromethane \\
\hline
\end{tabular}

$\begin{array}{llll}\mathrm{CS} & - & - & - \\ \mathrm{NPU}-\mathrm{CS} & - & - & - \\ { }^{a}(+: \text { Soluble; } & \pm \text { : partially soluble or swelled; } & - \text { : insoluble), } 25{ }^{\circ} \mathrm{C} \text {, } \\ 48 \text { hours, and chitosan: reagent }=1: 1.5 . & \end{array}$

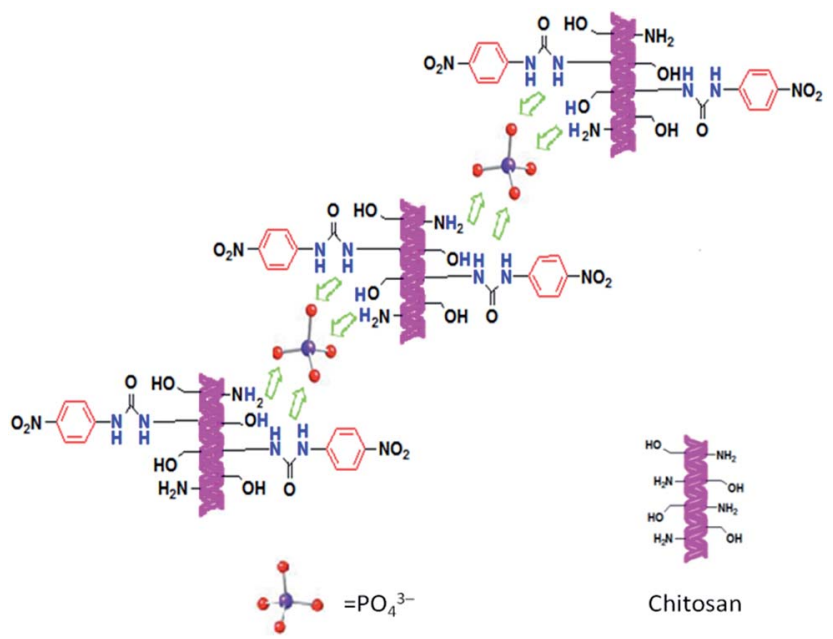

Scheme 2 The possible structure of the complex formed between the receptor with $\mathrm{PO}_{4}{ }^{3-}$.

basicity of the $\mathrm{A}^{-}$anion; the higher anion basicity, the stronger the hydrogen-bonding interaction.

Phenylurea-chitosan receptor was selective toward $\mathrm{PO}_{4}{ }^{3-}$, forming stable complexes. The possible reasons are as follows: (i) the attachment of the strong electron-withdrawing group $\left(-\mathrm{NO}_{2}\right)$ to the aromatic substituent in receptor $\mathrm{L}$ enhances the acidity of the urea NH proton, which could increase the stability of the $\mathrm{PO}_{4}{ }^{3-}$ complex. (ii) Many urea, hydroxyl and amino groups in phenylurea-chitosan receptor can form multiple hydrogen bond donors. The complex stability highly depends on the strength and the number of the H-bonds. ${ }^{10}$ The incorporation of additional $\mathrm{H}$-bonding groups to the receptor, in principle, leads to the formation of more stable anion complexes. (iii) The basicity of phosphate anions also strongly contributes to the selectivity of CS-NPU to phosphate anions. (IV) Urea is an appropriate receptor for oxoanions because it can form two $\mathrm{N}-\mathrm{H} \mathrm{O}$ bonds with two consecutive oxygen atoms of the anion. The proposed anion-sensing mechanism of CS-NPU with anions in $\mathrm{DMSO} / \mathrm{H}_{2} \mathrm{O}$ solution is depicted in Scheme 2.

Fluoride is a particular case as it has a size comparable to that of oxygen but holds an integral negative charge. Thus, among anions, $\mathrm{F}^{-}$establishes the strongest $\mathrm{H}$-bond interaction with an $\mathrm{NH}$ fragment of the urea subunit. In particular, the interaction should correspond to an advanced stage of the proton transfer. In addition, the highest value with $\mathrm{F}^{-}$was observed and explained by its high charge density, small dimension and high basicity. In the presence of strong electronwithdrawing groups on the receptor, there is also a possibility for double deprotonation of the urea receptor with $\mathrm{F}^{-}$.

\section{Conclusions}

In summary, we reported the synthesis and anion recognition characteristics of a new chitosan compound. During the addition of $\mathrm{PO}_{4}{ }^{3-}$ and $\mathrm{F}^{-}$anions, the sensor responded and could be detected with naked-eyes via a change from colourless to yellow for $\mathrm{PO}_{4}{ }^{3-}$ and yellowish for $\mathrm{F}^{-}$at room temperature. Other 
anions such as $\mathrm{Cl}^{-}, \mathrm{Br}^{-}, \mathrm{I}^{-}, \mathrm{NO}_{3}{ }^{-}, \mathrm{PF}_{6}{ }^{-}, \mathrm{ClO}_{4}{ }^{-}, \mathrm{AcO}^{-}, \mathrm{H}_{2} \mathrm{PO}_{4}{ }^{-}$, $\mathrm{HSO}_{4}{ }^{-}$, and $\mathrm{SO}_{4}{ }^{2-}$ had no response. The mechanism of this anion receptor is likely hydrogen bonding interactions.

\section{Conflicts of interest}

There are no conflicts to declare.

\section{Acknowledgements}

This work was supported by the National Natural Science Foundation of China (Grant no. 21271149).

\section{References}

1 V. Amendola, L. Fabbrizzi and L. Mosca, Chem. Soc. Rev., 2010, 39, 3889-3915.

2 M. Wenzel, J. R. Hiscock and P. A. Gale, Chem. Soc. Rev., 2012, 41, 480-520.

3 P. A. Gale and T. Gunnlaugsson, Chem. Soc. Rev., 2010, 39, 3595-3596.

4 A. F. Li, J. H. Wang, F. Wang and Y. B. Jiang, Chem. Soc. Rev., 2010, 39, 3729-3745.

5 A. E. Hargrove, S. Nieto, T. Z. Zhang, J. L. Sessler and E. V. Anslyn, Chem. Rev., 2011, 111, 6603-6782.

6 E. M. Boyle, S. Comby, J. K. Molloy and T. Gunnlaugsson, J. Org. Chem., 2013, 78, 8312-8319.

7 T. Gunnlaugsson, P. E. Kruger, P. Jensen, J. Tierney, H. D. P. Ali and G. M. Hussey, J. Org. Chem., 2005, 70(26), 10875-10878.

8 B. Wu, X. Huang, J. Liang, Y. Liu, X.-J. Yang and H. M. Hu, Inorg. Chem. Commun., 2007, 10, 563-566.

9 K. Pandurangan, J. A. Kitchen and T. Gunnlaugsson, Tetrahedron Lett., 2013, 54, 2770-2775.

10 V. B. Bregović, N. Basarić and K. M. Majerski, Coord. Chem. Rev., 2015, 295, 80-124.

11 M. Y. Wei, S. G. Li, C. D. Jia and B. Wu, Chem. J. Chin. Univ., 2011, 32, 1939-1949.

12 J. M. Kang, J. H. Lee, Y. H. Kim, S. K. Lee, E. Y. Kim, H. G. Lee and C. Ki, J. Inclusion Phenom. Macrocyclic Chem., 2012, 74, 177-182.

13 D. D. Su, H. T. Niu, Y. Wang, J. Q. He and J. P. Cheng, Chem. J. Chin. Univ., 2010, 31, 714-717.

14 M. Boiocchi, L. D. Boca, D. Esteban-Gómez, L. Fabbrizzi, M. Licchelli and E. Monzani, J. Am. Chem. Soc., 2004, 126, 16507-16514.

15 J. Kang, Y. J. Lee, S. K. Lee, J. H. Lee, J. J. Park, Y. Kim, S. J. Kim and C. Kim, Supramol. Chem., 2010, 22, 267-273.

16 A. Aldrey, V. García, C. Lodeiro, A. Macías, P. Pérez-Lourido, L. Valencia, R. Bastida and C. Núñez, Tetrahedron, 2013, 69, 4578-4585.

17 J. Shao, H. Lin and H. K. Lin, Talanta, 2008, 75, 1015-1020.

18 Y. J. Kim, H. Kwak, S. J. Lee, J. S. Lee, H. J. Kwon, S. H. Nam, K. Lee and C. Kim, Tetrahedron, 2006, 62, 9635-9640.

19 X. L. Wang, C. D. Jia, X. J. Huang and B. Wu, Inorg. Chem. Commun., 2011, 14, 1508-1510.

20 R. A. A. Muzzarelli, Carbohydr. Polym., 2011, 84, 54-63.
21 M. N. V. Ravi Kumar, R. A. A. Muzzarelli, C. Muzzarelli, H. Sashiwa and A. J. Domb, Chem. Rev., 2004, 104, 6017-6084. 22 M. N. V. Ravi Kumar, React. Funct. Polym., 2000, 46, 1-27.

23 H. P. Li, H. Li and Y. Liu, Iran. Polym. J., 2016, 25, 277-284.

24 M. Eweis, S. S. Elkholy and M. Z. Elsabee, Int. J. Biol. Macromol., 2006, 38, 1-8.

25 S. S. Elkholy, H. A. Salem, M. Eweis and M. Z. Elsabee, Int. J. Biol. Macromol., 2014, 70, 199-207.

26 N. A. Mohamed and N. Y. Al-mehbad, Int. J. Biol. Macromol., 2013, 57, 111-117.

27 Z. H. Li, F. Yang and R. D. Yang, Int. J. Biol. Macromol., 2015, 75, 378-387.

28 Z. M. Zhong, R. E. Xing, S. Liu, L. Wang, S. B. Cai and P. C. Li, Carbohydr. Res., 2008, 343, 566-570.

29 M. Monier and D. A. Abdel-Latif, J. Hazard. Mater., 2012, 209-210, 240-249.

30 A. Rajeswari, A. Amalraj and A. Pius, J. Environ. Chem. Eng., 2015, 3, 2331-2341.

31 X. Liu and L. F. Zhang, Powder Technol., 2015, 277, 112-119.

32 N. Viswanathan, C. S. Sundaram and S. Meenakshi, J. Hazard. Mater., 2009, 161, 423-430.

33 J. Q. Xue, Y. J. Guo, Q. Bi, W. B. Mao and J. X. Li, Mod. Phys. Lett. B, 2013, 27, 1341031.

34 S. Tang, J. D. Liu, Q. Bin, K. Q. Fu, X. C. Wang, Y. B. Luo, S. H. Huang and Z. W. Bai, J. Chromatogr. A, 2016, 1476, 53-62.

35 R. Raghunandhan, L. H. Chen, H. Y. Long, L. L. Leam, P. L. So, X. Ning and C. C. Chan, Sens. Actuators, B, 2016, 233, 31-38.

36 M. Monier, D. A. Abdel-Latif and Y. G. Abou El-Reash, J. Colloid Interface Sci., 2016, 469, 344-354.

37 V. N. Mehta, H. Basu, R. K. Singhal and S. K. Kailasa, Sens. Actuators, B, 2015, 220, 850-858.

38 K. Chauhan, P. Singh and R. K. Singhal, ACS Appl. Mater. Interfaces, 2015, 7, 26069-26078.

39 L. Wang, W. Wen, H. Y. Xiong, X. H Zhang, H. S. Gu and S. F. Wang, Anal. Chim. Acta, 2013, 758, 66-71.

40 M. Darder, M. Colilla and E. Ruiz-Hitzky, Appl. Clay Sci., 2005, 28, 199-208.

41 X. Yao, G. H. Lu, X. G. Wu and T. Zhan, Electroanalysis, 2001, 13, 923-926.

42 A. Yu. Mironenko, A. A. Sergeev, A. E. Nazirov, E. B. Modin, S. S. Voznesenskiy and S. Y. Bratskaya, Sens. Actuators, B, 2016, 225, 348-353.

43 I. M. El-Sherbiny, A. Hefnawy and E. Salih, Int. J. Biol. Macromol., 2016, 86, 782-788.

44 A. Bayram, C. Ozbek, M. Şenel and S. Okur, Sens. Actuators, B, 2017, 241, 308-313.

45 K. C. Gupta and F. H. Jabrail, Carbohydr. Polym., 2006, 66, 43-54.

46 X. Jiang, L. R. Chen and W. Zhong, Carbohydr. Polym., 2003, 54, 457-463.

47 L. Y. Chen, Y. M. Du and H. Q. Wu, J. Appl. Polym. Sci., 2002, 82, 1233-1241.

48 Z. K. Wang, S. J. Chen, J. W. Y. Lam, W. Qin, R. T. K. Kwok, N. Xie, Q. L. Hu and B. Z. Tang, J. Am. Chem. Soc., 2013, 135, 8238-8245. 
49 M. J. Su, W. Wan, X. Yong, X. W. Lu, R. Y. Liu and J. Q. Qu, Chin. J. Polym. Sci., 2013, 31, 620-629.

50 S. P. Chen, G. Z. Wu and H. Y. Zeng, Carbohydr. Polym., 2005, 60, 33-38.

51 C. M. Fernandez, J. Heinamaki, M. Rasanen, S. L. Maunu, M. Karjalaien, O. M. NietoAcosta, A. Iraizoz Colarte and J. Yliruusi, Carbohydr. Polym., 2004, 58, 401-408.

52 M. Lavertu, A. Xia, A. N. Serreqi, M. Berrada, A. Rodrigues, D. Wang, M. D. Buschmann and A. Gupta, J. Pharm. Biomed. Anal., 2003, 32, 1149-1158.
53 M. Rinaudo, Prog. Polym. Sci., 2006, 31, 603-632.

54 E. S. Abdou, K. S. A. Nagy and M. Z. Elsabee, Bioresour. Technol., 2008, 99, 1359-1367.

55 M. Monier, D. A. Abdel-Latif and Y. G. Abou El-Reash, J. Colloid Interface Sci., 2016, 469, 344-354.

56 O. Ahmet, S. Erdemir and O. Kocyigit, J. Mol. Struct., 2013, 1048, 392-398.

57 M. Takeuchi, M. Ikeda, A. Sugasaki and S. Shinkai, Acc. Chem. Res., 2001, 34, 865-873.

58 D. H. Lee, K. H. Lee and J. I. Hong, Org. Lett., 2001, 3, 5-8. 